\title{
Sequestration of the exocytic SNARE Psy1 into multiprotein nodes reinforces polarized morphogenesis in fission yeast
}

Kristi E. Miller, Joseph O. Magliozzi, Noelle A. Picard, and James B. Moseley ${ }^{\dagger}$

Department of Biochemistry and Cell Biology, The Geisel School of Medicine at Dartmouth, Hanover, NH 03755.

†To whom correspondence should be addressed. E-mail: james.b.moseley@dartmouth.edu, Tel: (603) 650-1159.

Running Head: Psy1 nodes reinforce cell polarity

Number of characters (excluding Materials and Methods; and References): 19,875 characters

Key words: Cell morphology, polarity, exocytosis, Schizosaccharomyces pombe, Psy1, Skb1.

Abbreviations: GAP, GTPase-activating protein; PM, plasma membrane; WT, wild type; FRAP, Fluorescence recovery after photobleaching; temperature-sensitive, ts; potassium chloride, $\mathrm{KCl}$; SNARE, soluble N-ethylmaleimide-sensitive factor-attachment protein receptors. 


\begin{abstract}
Polarized morphogenesis is achieved by targeting or inhibiting growth at distinct regions. Rodshaped fission yeast cells grow exclusively at their ends by restricting exocytosis and secretion to these sites. This growth pattern implies the existence of mechanisms that prevent exocytosis and growth along non-growing cell sides. We previously identified a set of 50-100 megadalton-sized node structures along the sides of fission yeast cells that contain the interacting proteins Skb1 and Slf1. Here, we show that Skb1-Slf1 nodes contain the syntaxin-like SNARE Psy1, which mediates exocytosis in fission yeast. Psy1 localizes in a diffuse pattern at cell tips where it promotes exocytosis and growth, but Psy1 is sequestered in Skb1-Slf1 nodes at cell sides where growth does not occur. Mutations that prevent node assembly lead to aberrant exocytosis at cell sides causing increased cell width, and these defects are exacerbated during osmotic stress. Genetic results indicate that this Psy1 node mechanism acts in parallel to actin cables and Cdc42 regulation. Our work suggests that sequestration of syntaxin-like Psyl at non-growing regions of the cell cortex reinforces cell morphology by restricting exocytosis to proper sites of polarized growth.
\end{abstract}

\title{
INTRODUCTION
}

Cell polarization is critical for the function of nearly every cell type and underlies essential processes such as cell growth and division. Regardless of how elaborate or simple a cell shape, polarized morphogenesis is achieved by targeting growth to specific regions. At the same time, polarized morphogenesis requires separate mechanisms that inhibit growth at other regions, thereby restricting growth to defined sites of polarity (Goehring and Grill, 2013). Fission yeast cells exhibit a highly polarized pattern of growth, making them an ideal model to study morphology and polarity. These rod-shaped cells maintain a constant cell width and grow exclusively from their tips by restricting exocytosis and secretion to these sites during interphase. During division, fission yeast redirect polarized exocytosis and secretion to the cell middle for septation and cell separation (Mitchison and Nurse, 1985; Kelly and Nurse, 2011; Das et al., 2007).

The growth machinery at cell tips has been widely studied (Reviewed by Martin and Arkowitz, 2013; Chiou et al., 2017). Landmark proteins such as Teal and Tea4 are deposited at cell ends by microtubules (Mata and Nurse, 1997; Feierbach et al., 2004; Martin et al., 2005; Tatebe et al., 2005). Landmark proteins recruit polarity factors including the formin For3 and its regulators, which assemble actin cables oriented toward cell tips (Feierbach et al., 2001; Martin et al., 2005; Martin and Chang, 2006; Martin et al., 2007). Actin cables act as tracks for myosinbased delivery of secretory vesicles, leading to targeted exocytosis of cell wall proteins and modifying enzymes at cell tips (Pruyne et al., 2004). At cell tips, a multiprotein complex called the exocyst tethers secretory vesicles for subsequent membrane fusion and content release mediated by SNAREs (soluble N-ethylmaleimide-sensitive factor-attachment protein receptors) (TerBush et al., 1996; Südhof and Rothman, 2009; Polgar and Fogelgren, 2018; Ganesan et al., 2020). SNARE proteins mediate membrane fusion in yeast and human cells, thus providing specificity by ensuring that only correctly targeted vesicles fuse (Protopopov et al., 1993; Sollner et al., 1993; Rothman, 1994; Pelham, 1999). Actin cables and the exocyst act in parallel to promote growth specifically at the tips of fission yeast (Bendezu and Martin, 2011; Snaith et al., 2011). 
Mechanisms that promote growth at cell tips need to be reinforced by separate mechanisms that inhibit growth at cell sides. Previous studies identified Rga4 and Rga6, which are inhibitory GAPs (GTPase activating proteins) for the Rho GTPase Cdc42, along cell sides (Das et al., 2007; Tatebe et al., 2008; Kelly and Nurse, 2011; Revilla-Guarinos et al., 2016). These GAPs help to restrict Cdc42 activation and polarized growth to cell tips, but it has been unclear if other mechanisms exist to prevent exocytosis along cell sides. Here, we show that the fission yeast syntaxin-like SNARE protein Psyl has different localization patterns at cell tips versus along cell sides. Psy1 forms a diffuse band at growing cell tips but localizes as cortical puncta along the non-growing cell sides. These puncta are the previously identified megadaltonsized node structures formed by the interacting proteins Skb1 and Slf1. We show that nodes sequester Psyl at non-growing cortical sites to restrict exocytosis to proper sites of polarized growth.

\section{RESULTS AND DISCUSSION}

\section{Psy1 forms growth-positioned nodes}

We noticed the presence of punctate structures in some localization images of Psy1 from previous studies (Wang et al., 2016; Zhu et al., 2018). Though typically considered a diffuse marker for the plasma membrane (PM), these images raised the possibility of a more intricate localization pattern. Therefore, we imaged GFP-Psyl and collected series of z-sections to capture the full cell volume. At growing cell tips, Psyl localized as diffuse bands at the PM. In contrast, along the non-growing cell middle Psy1 localized to discrete puncta on the PM (Figure 1A, left GFP-Psy1 panel). We observed these same Psy1 puncta using epifluorescence, laser-scanning confocal, and spinning disk confocal microscopy, so they do not represent an artifact of any particular imaging system. The distribution of Psyl puncta suggested a link to cellular growth patterns. Psy1 puncta were excluded from sites of cell growth marked by the actin probe LifeactmCherry (Figure 1A). More specifically, Psy1 puncta were excluded from one end of small monopolar cells during interphase. In bipolar cells, Psy1 puncta were present at the cell middle and did not overlap with cortical actin patches at either growing end. In dividing cells, when actin and growth are redirected to the cell middle, Psyl puncta were absent from the division septum. We conclude that Psy1 localizes in puncta at nongrowing regions of the cell cortex.

\section{Psy1 is a component of Skb1-Slf1 nodes}

Psyl puncta bear striking resemblance to a set of cortical node structures that we identified in previous studies (Deng and Moseley, 2013; Deng et al., 2014). These megadaltonsized nodes contain two interacting proteins called Skb1 and Slf1. We examined co-localization of Psyl with these node proteins to test the possibility that Psyl might be a component of Skb1Slf1 nodes. In cells expressing mCherry-Slf1 and GFP-Psy1, we found that Psy1 and S1f1 colocalize in the same cortical nodes (Figure 1B). In addition to co-localization, Psy1 coimmunoprecipitated with both Skb1 and Slf1 (Figure 1C). Thus, Psy1 localizes to Skb1-Slf1 nodes and physically associates with these proteins. These results indicate that cortical nodes are multiprotein structures containing Skb1, Slf1, and Psy1.

We sought quantitative insight into the relationship between Skb1, Slf1, and Psy1 at nodes. By quantitative fluorescence microscopy, Skb1 and Slfl are roughly stoichiometric at 
nodes, with each node containing on average 69 Skb1 molecules and 77 Slf1 molecules (Deng et al., 2014). The global concentration of GFP-Psy1 in cells was higher than either Skb1 or Slf1. At nodes, we measured slightly higher average signal for GFP-Psyl than for Slf1 or Skb1 (Figure 1D). Based on these data, we estimate that each node contains $\sim 100$ molecules of Psy1, although this number is likely to fluctuate between different nodes.

We tested if Psy1 localization to nodes requires Skb1 and/or Slf1. GFP-Psy1 localization to nodes was lost in either $s k b 1 \Delta$ or $s l f 1 \Delta$ mutant cells (Figure 1E). In both mutants, GFP-Psy 1 localized in a diffuse pattern throughout the PM. This result is consistent with the interdependence of Skb1 and Slf1 for node formation (Deng et al., 2014). We conclude that Skb1 and Slf1 associate to form cortical nodes, which then recruit Psy1 to these structures through physical interactions.

\section{Psy1 protein is trapped in nodes}

Next, we examined the dynamics of Psyl at nodes. We performed fluorescence recovery after photobleaching (FRAP) of individual nodes. A bleached GFP-Psyl node did not recover fluorescence after 10 minutes (Figure 2A), similar to FRAP results from bleaching Psy1 along cell sides in previous studies (Bendezu et al., 2015; Wang et al., 2016; Tay et al., 2019). This result indicates that Psyl protein is trapped in a node and does not exchange freely with Psy1 outside the node. This finding was supported by time-lapse imaging of Psyl nodes. We observed dynamic changes in Psyl distribution at cell tips, but Psyl at nodes did not move or rapidly disassemble over time (Figure 2B), similar to Skb1 and Slfl (Deng and Moseley, 2013; Deng et al., 2014).

As an additional test of Skb1-Slf1-Psy1 node stability, we treated cells with 1,6hexanediol, which disrupts weak hydrophobic interactions (Patel et al., 2007; Ribbeck and Gorlich, 2002). This chemical disrupts P-body granules in fission yeast cells (Kroschwald et al., 2015), which we confirmed in control experiments (Figure S1A). Treatment of cells expressing mCherry-Slf1 and GFP-Psy1 with 10\% 1,6-hexanediol or DMSO control did not have a dramatic effect on Skb1-Slf1-Psy1 node stability (Figure 2C), although we note that a minor portion of Slf1 was displaced from nodes (Figure S1B). This result indicates that Skb1-Slf1-Psy1 nodes are held together by interactive forces distinct from condensates such as P-bodies. Overall, our experiments reveal that nodes are static structures that trap Psy1 protein at cell sides.

\section{Genetic interactions implicate Skb1-SIf1 nodes in exocytosis}

What is the function of Psyl localization at cortical nodes? Psy1 is necessary for exocytosis and growth at cell tips where it localizes independently of node proteins. At nongrowing regions Psy1 stably associates with Skb1-Slf1 nodes. We hypothesized that nodes might sequester Psy1 to inhibit exocytosis and growth along the cell middle. As a first test, we examined genetic interactions between node mutants and exocytosis mutants. In both $s k b 1 \Delta$ and slf1 $\Delta$ mutants, Psy1 is not trapped at nodes and instead localizes diffusively throughout the PM including along cell sides (Figure $1 \mathrm{E}$ ). We combined $s k b 1 \Delta$ or $s l f 1 \Delta$ with several mutations affecting exocyst function: the temperature-sensitive (ts) exocyst subunit mutants $\sec 8-1$ and sec3-2, deletion of non-essential exocyst subunit Exo70, and deletion of the non-essential exocyst activator Rho3 (Wang, H. et al., 2003; Wang et al., 2002; Bendezu et al., 2012). Additionally, we combined $s k b 1 \Delta$ or $s l f 1 \Delta$ with for $3 \Delta$, which abolishes actin cables that direct 
polarized transport of exocytic secretory vesicles (Feierbach and Chang, 2001; Nakano et al., 2002). We discovered synthetic growth defects for $s k b 1 \Delta$ exo $70 \Delta$ and $s k b 1 \Delta$ for $3 \Delta$ mutants, while

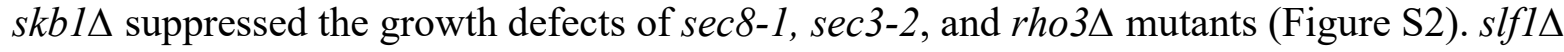
showed similar but less pronounced phenotypes. Mutations that affect exocytosis cause cell separation defects because exocytosis contributes to formation and remodeling of the division septum (Wang H et al., 2002; Bendezu et al., 2012; Jourdain et al., 2012; Wang N et al., 2016). Thus, we assayed the septation index in these double mutants and found increased septation index for $s k b 1 \Delta$ exo $70 \Delta$ double mutants compared to single mutants alone (Figures $3 \mathrm{~A}-\mathrm{B}$ ). In

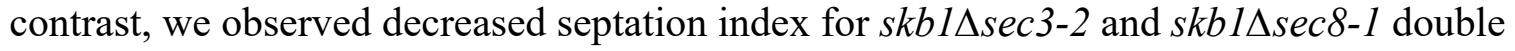
mutants compared to sec8-1 or sec3-2 alone, similar to growth suppression (Figure $\mathrm{S} 2$ ). The synthetic defects observed with skb1 $\operatorname{exo} 70 \Delta$ and $s k b 1 \Delta$ for $3 \Delta$ mutants suggest that Skb1 may share a redundant function with Exo70 and For3 in spatial control of exocytosis. If release of sequestered Psyl from nodes underlies $s k b 1 \Delta$ suppression of mutants such as $\sec 3-2$, then extra dosage of Psyl might provide similar suppression even in the presence of nodes. Indeed, addition of the $p R E P 41-G F P$-psyl plasmid, which results in excess psyl expression, suppressed the ts growth of sec3-2 mutants (Figure 3C). These genetic interactions suggest that Skb1-Slf1-Psy1 nodes function in regulating exocytosis.

\section{Loss of Skb1-Slf1-Psy1 nodes leads to ectopic exocyst at cell sides}

Based on these genetic interactions, we performed a series of microscopy-based experiments to test the role of Skb1-Slf1-Psy1 nodes in spatial control of exocytosis. Polarized exocytosis delivers the $\beta$-glucan synthase subunit Bgs4 to sites of active growth for cell wall synthesis (Cortes et al., 2005, 2015). In FRAP assays, photobleached GFP-Bgs4 signal at cell tips and the division site recovers rapidly due to polarized delivery of secretory vesicles at these sites (Figure $4 \mathrm{~A}$ ). We found that $s k b 1 \Delta$ caused a significant decrease in the plateau of this recovery (Figure 4B), but the rate of recovery was unaffected. This result means that loss of nodes reduces the mobile pool of Bgs4 that is delivered to sites of polarized growth and raises the possibility that the exocytic machinery is directed to ectopic locations in $s k b 1 \Delta$ cells. To test this possibility, we directly imaged exocyst component Sec5. In the presence of $0.5 \mathrm{M} \mathrm{KCl}$, Sec5GFP localized to growing cell tips and to the cell division site of WT cells. In contrast, Sec5GFP appeared at ectopic sites along cell sides in $s k b 1 \Delta$, slfl $1 \Delta$, and $s k b 1 \Delta$ slfl $1 \Delta$ cells under similar conditions (Figure 4C). We conclude that Skb1-Slf1-Psy1 nodes sequester Psy1 as part of the cellular system that generates spatial control of exocytosis.

Because disruption of Skb1-Slf1-Psy1 nodes did not lead to aberrant exocyst localization in the absence of osmotic stress, we tested the possibility that nodes act in parallel with other mechanisms to prevent exocytosis along cell sides. For example, the Cdc42 GAPs Rga4 and Rga6 localize along cell sides to prevent Cdc42 activation at these sites (Das et al., 2007; Tatebe et al., 2008; Kokkoris et al., 2014; Revilla-Guarinos et al., 2016). In time-lapse images of unstressed cells lacking both nodes and Cdc42 GAPs, we observed ectopic localization of the exocyst component Sec8-mNG in the middle of cells (Figure 4D). Importantly, these defects were more severe in $s k b 1 \Delta$ rga $4 \Delta$ rga $6 \Delta$ triple mutant cells than in $s k b 1 \Delta$ or rga $4 \Delta$ rga $6 \Delta$ mutants alone (Figure 4E). To extend this result, we performed similar analysis for cells lacking nodes and actin cables, which target secretory vesicles away from cell sides. Combining node and cable mutations in the $s k b 1 \Delta$ for $3 \Delta$ double mutant led to aberrant localization of Sec8-mNG at cell sides (Figures 4D-E). Together, these results show that nodes sequester Psy1 to prevent 
mislocalization of the exocytic machinery to cell sides and act in parallel with other mechanisms including Cdc42 GAPs and actin cables.

\section{Skb1-SIf1-Psy1 nodes help to maintain cell width}

The spatial pattern of exocytosis defines fission yeast cell morphology, as localized secretion of cell wall proteins and modifying enzymes leads to cell growth (Bendezú and Martin, 2011; Atilgan et al., 2015; Abenza et al., 2015). Our results show that Skb1-Slf1-Psy1 nodes inhibit exocytosis at cell sides together with additional mechanisms mediated by Rga4, Rga6, and For3. Defects in spatial control of exocytosis should lead to morphological consequences in cell shape. We found that cells lacking Skb1 were slightly wider than WT cells, but this difference was not statistically significant. Previous studies identified a cell width defect for mutants in rga4 $\Delta$, rga6 $\Delta$, and for $3 \Delta$ (Feierbach and Chang, 2001; Das et al., 2007; RevillaGuarinos et al., 2016). Since $s k b 1 \Delta$ exhibited synthetic defects with these other mutants in positioning exocytosis, we tested their combined effects on cell morphology. We found that $s k b 1 \Delta$ was additive with $r g a 6 \Delta$ and for $3 \Delta$ in increasing cell width, as the double mutants $s k b 1 \Delta$ rga $6 \Delta$ and $s k b 1 \Delta$ for $3 \Delta$ were significantly wider than any of the single mutants alone (Figure 5A). Furthermore, $s k b 1 \Delta$ rga $4 \Delta$ double mutant cells were wider than either single mutant alone, although this trend was not statistically significant. Cells lacking Slf1 showed similar results to $s k b 1 \Delta$ but the effect was less pronounced (Figure S3A), which may be due to additional functions for Skb1 as suggested by previously noted differences in $s k b 1 \Delta$ and $s l f 1 \Delta$ phenotypes (Deng et al., 2014). These combined results indicate that Skb1-Slf1 nodes sequester Psy1 at the cell middle to prevent aberrant exocytosis and this mechanism works in parallel to previously identified mechanisms including Cdc42 GAPs and actin cables. Consistent with Skb1-Slf1-Psy1 nodes functioning independently of Cdc42 GAPs at cell sides, nodes do not co-localize with Rga4 or Rga6 (Figure S3B). Overall, these results suggest that Skb1 works in parallel with Cdc42 GAPs and actin cables for polarized morphogenesis.

\section{Model for polarized morphogenesis in fission yeast}

In this study, we have shown that Psyl is sequestered in Skb1-Slf1 nodes at non-growing regions of the PM to prevent ectopic exocytosis at these sites. Our genetic experiments reveal that this new mechanism acts in parallel to actin cable transport and Cdc42 GAPs (Figure 5C). This demonstrates that ectopic growth along cell sides is inhibited by multiple mechanisms that reinforce cell morphology, in particular for control of cell width. We anticipate that signaling pathways that control Psyl nodes, actin cables, and Cdc42 GAPs are further reinforced by physical barriers to exocytosis at cell sides such as the cortical endoplasmic reticulum ( $\mathrm{Ng}$ et al., 2018). This combination of mechanisms along cell sides supports the notion that cell polarity arises from multiple activities that affect different steps in the trafficking, docking, and fusion of exocytic secretory vesicles.

Sequestration of Psy1 into nodes by Skb1-Slf1 has implications for SNARE proteins beyond yeast. We note that SNARE proteins have been shown to be clustered and sequestered in human cells with connection to several diseases. For example, individuals with insulin resistance exhibit sequestration of SNAP-23 (synaptosomal-associated protein of $23 \mathrm{kDa}$ ) by lipid droplets, thus blocking exocytosis of glucose transporters (Boström et al., 2007). In addition, SNAREs are aberrantly sequestered in cholesterol-enriched regions of LSD (lysosomal storage disorder) 
endolysosomal membranes. This abnormal spatial organization locks SNAREs in complexes and impairs their sorting and recycling (Fraldi et al., 2010). Alpha-synuclein aggregates preferentially sequester SNAP-25 and VAMP-2 (vesicle-associated membrane protein 2) leading to reduced exocytosis and contributing to neurotoxicity (Choi et al., 2018). Skb1 and/or Slf1 could also regulate Psyl activity beyond this sequestration mechanism, a possibility that can be tested in future work. Overall, regulated sequestration of SNARE proteins may be a general mechanism leading to inhibition of exocytosis in a wide range of cell types and organisms.

\section{MATERIALS AND METHODS}

\section{Strains, plasmids, and growth conditions}

Standard methods were used to grow and culture $S$. pombe cells (Moreno et al., 1991). Yeast strains used in this study are listed in Supplemental Table S1. Gene fusions were expressed from their endogenous promoters unless otherwise indicated. One-step PCR-based homologous recombination was performed for tagging or deletion of genes on the chromosome (Bähler et al., 1998). To obtain N-terminal GFP-tagged Psy1, the $p s y 1+$ promoter was amplified using primers containing BglII and PacI sites at the 5' and 3'ends, respectively. This PCR product was inserted in place of the $P 3 n m t 1$ promoter in the $p F A 6 A-k a n M X 6-P 3 n m t 1-G F P$ plasmid. PCR product from the $p F A 6 A-k a n M X 6-p s y 1+-G F P$ plasmid was inserted adjacent (at the 5' end) to the psyl open reading frame on the chromosome. Slf1 N-terminal mCherry tagging was described previously (Deng et al., 2014). To generate pREP41-GFP-psyl for overexpression of GFP-Psy1, genomic DNA from a WT yeast strain was used as a template and the psyl gene was amplified using primers with SalI and BamHI at the 5' and 3'ends, respectively. The PCR product was inserted into the MCS of $p R E P 41-G F P$ creating $p R E P 41-G F P-p s y 1$ (pJM1359). For Psy1 overexpression assays, plasmids were transformed into fission yeast cells and spread on EMMLeu plates supplemented with $10 \mu \mathrm{g} / \mathrm{ml}$ thiamine to select for plasmid-containing cells. In Figure $3 \mathrm{C}$, mid-log-phase cells in EMM-Leu with $10 \mu \mathrm{g} / \mathrm{ml}$ thiamine grown at $25^{\circ} \mathrm{C}$ were collected and resuspended in the same medium and spotted by 10x serial dilutions on EMM-Leu plates supplemented with $10 \mu \mathrm{g} / \mathrm{ml}$ thiamine. Plates were incubated at $37^{\circ} \mathrm{C}$ for 4 days before imaging. The presence of excess GFP-Psyl with thiamine was confirmed by fluorescence microscopy. To measure cell width at division (Figure 5A and S3A), prototrophic strains were grown in EMM4S medium at $32^{\circ} \mathrm{C}$ and stained with Blankophor prior to imaging. To determine the septation index of cells (Figure $3 \mathrm{~A}$ ), cells were grown at $25^{\circ} \mathrm{C}$ in EMM4S medium and then cultures were shifted to $32^{\circ} \mathrm{C}$ or $37^{\circ} \mathrm{C}$ for $5 \mathrm{~h}$ before staining with Blankophor and imaging. In Figure $4 \mathrm{C}$ for $\mathrm{KCl}$ treatment, cells were initially cultured at $25^{\circ} \mathrm{C}$ in EMM4S medium and were then shifted to EMM4S medium containing $0.5 \mathrm{M} \mathrm{KCl}$ for $3.5 \mathrm{~h}$ prior to imaging. In Figure $2 \mathrm{C} \& \mathrm{~S} 1$, cells were grown at $25^{\circ} \mathrm{C}$ in EMM4S medium and then treated with 10\% 1,6-hexanediol or DMSO for 45 min prior to imaging.

\section{Co-immunoprecipitation and immunoblotting}

Co-immunoprecipitation of proteins from fission yeast cell extracts were performed using a protocol adapted from Deng and Moseley, 2013. For Figure 1C, mCherry-S1f1 and GFP-Psy1 co-immunoprecipitation was performed using $50 \mathrm{~mL}$ of $0.5 \mathrm{OD}_{595}$ cells grown in YE4S at $25^{\circ} \mathrm{C}$. Cells were harvested by centrifugation, washed 1x in MQ water and resuspended in $400 \mu 1$ of Lysis Buffer (20 mM HEPES (4-(2-hydroxyethyl)-1-piperazineethanesulfonic acid) pH 7.4, 200 
$\mathrm{mM} \mathrm{NaCl}, 1 \%$ Triton X-100, 1mM phenylmethylsulfonyl fluoride, complete EDTA-free protease inhibitor tablets [Roche, Indianapolis, IN]) together with $200 \mu \mathrm{l}$ of glass beads and lysed using a Mini-beadbeater-16 (BioSpec, Bartlesville, OK; two cycles of 1 minute at max speed). Lysates were spun at $14,000 \mathrm{x} g$ for 10 minutes at $4^{\circ} \mathrm{C}$ and supernatants were recovered. anti-GFP magnetic beads (Allele Biotech) were washed 3x in Lysis Buffer and added to clarified cell lysates and rotated for 2 hours at $4^{\circ} \mathrm{C}$. After lysate removal, beads were washed $5 \mathrm{x}$ in Lysis Buffer and resuspended in SDS-PAGE sample buffer $(65 \mathrm{mM}$ Tris, $\mathrm{pH}$ 6.8, 3\% SDS, 10\% glycerol, $10 \% 2$-mercaptoethanol) and boiled for 5 minutes at $99^{\circ} \mathrm{C}$ followed by SDS-PAGE and western blotting.

For detection of 6His-Skb1 and GFP-Psy1 interaction, pJM685 (pREP3x-6His-Skb1) or pJM210 (pRep3x) was transformed into appropriate strains and colonies were selected on EMMLeu $+10 \mu \mathrm{g} / \mathrm{mL}$ thiamine plates. Cells were grown in $50 \mathrm{~mL}$ EMM-Leu $+10 \mu \mathrm{g} / \mathrm{mL}$ thiamine until reaching a $0.5 \mathrm{OD}_{595}$. Co-immunoprecipitation and SDS-PAGE followed by western blotting was carried out as mentioned above except TALON metal affinity resin (Takara) was used instead of anti-GFP beads for 6His-Skb1 enrichment.

Western blots were probed with anti-6His (SC-8036; Santa Cruz Biotechnology), antiGFP (Moseley et al., 2009), and anti-RFP (NBP1-69962; Novus Biologicals) antibodies.

\section{Microscopy and image analysis}

Fission yeast cells were grown in EMM4S medium to logarithmic phase for imaging. Time-lapse imaging was performed using a spinning disk confocal (Andor CSU-WI system, Nikon software) equipped with a 100x 1.45 NA CFI Plan Apochromat Lambda objective lens (Nikon); $405 \mathrm{~nm}, 445 \mathrm{~nm}, 488 \mathrm{~nm}, 560 \mathrm{~nm}, 637 \mathrm{~nm}$ and $685 \mathrm{~nm}$ laser lines; and a Andor Zyla camera on an inverted microscope (Ti-E, Nicon). For most time-lapse imaging, single z-slice images were captured every 1 or $3 \mathrm{sec}$ using cells mounted on an agarose slab at room temperature.

All static images of fission yeast cells (with the exception of Figure 1B, taken with the spinning disk confocal) were taken at room temperature with a DeltaVision Imaging System (Applied Precision), equipped with an Olympus IX-71 inverted wide-field microscope, a Photometrics CoolSNAP HQ2 camera, and Insight solid-state illumination. Most images were acquired with $11 \mathrm{z}$-stacks and $0.4 \mu \mathrm{m}$ step using cells mounted in EMM4S liquid media. Images were iteratively deconvolved using SoftWoRx software (Applied Precision), as indicated in figure legends.

Image processing and analysis were performed using Image J (National Institutes of Health). Figures were generated using maximum intensity projections of z-stacks for fluorescent images and a single middle $\mathrm{z}$-section for DIC images, unless otherwise indicated in the figure legend. For global intensity quantification of GFP tagged Psy1, Skf1, or Slf1 (Figure 1D), sum intensity projections were created from images (40 z-sections, $0.17 \mu \mathrm{m}$ spacing), and an ROI was drawn around the outline of cells. The intensity of an equal sized ROI with no cell present was used to subtract background. For the mean intensity (integrated density) per node measurements (Figure 1D), sum projections were created from the top half of cell z-stack that encompass one side of the cell membrane. An ROI was drawn around each individual node (measured 175 nodes per strain) and background was subtracted using the intensity of an equal sized ROI with no node present. Images used to obtain these measurements were taken with a Zeiss LSM 880 laser scanning confocal microscope (See below). To quantify mean Sec8-mNG intensity in the cell middle over time (Figure 4E), the intensity of an equal sized ROI with no cell present was used 
to subtract background from selected cells. Using the segmented line tool, a line was drawn from the middle of cell tips along the side of the cells. Kymographs were generated using the multiple kymograph plug-in for ImageJ to display Sec8-mNG signal over time along the line. The mean Sec8-mNG intensity over time in the cell middle was measured from the kymograph. The same sized box was drawn to cover the same width along the cell side for all cell types. Intensity values were normalized to the average Sec8-mNG intensity in the cell middle of WT cells and plotted on a graph (Figure 4E).

\section{FRAP analysis}

To perform FRAP experiments (Figure 4A-B), images were captured at a single z-section on an agar pad at room temperature using a Zeiss LSM 880 laser scanning confocal microscope equipped with 100X alpha Plan-Apochromat/NA 1.46 Oil DIC M27 Elyra objective, GaAsP Detectors, and Zen Blue acquisition software. The middle focal plane of cells was chosen to bleach. After collecting 3 prebleach images, selected ROIs were bleached to $<50 \%$ of the original fluorescence intensity using the laser scanner. Postbleach images were acquired for a duration long enough so that the recovery curve reached a plateau. After background subtraction and correcting for photobleaching, the data were normalized to the mean prebleach intensity of the ROI and set to $100 \%$. The intensity just after bleaching was set to $0 \%$ so that FRAP curves represent the percent recovery of fluorescent signal. The intensity of every three consecutive postbleach time points was averaged to reduce noise. The intensity data were plotted and fitted using the exponential equation $\mathrm{y}=\mathrm{m} 1+\mathrm{m} 2 * \exp (-\mathrm{m} 3 * \mathrm{X})$, where $\mathrm{m} 3$ is the off-rate, using Prism 8 (GraphPad Software). The half-time of recovery was calculated using the equation $t 1 / 2=$ $(\ln 2) / \mathrm{m} 3$.

For GFP-Psy1 FRAP at a single node (Figure 2A), a circular ROI was used to photobleach one GFP-Psyl node and $0.17 \mu \mathrm{m}$ sized z-sections were taken to capture the top half of the cell to encompass the entire node. Image stacks were captured every 60 seconds. Images shown are sum projections of the top half of cells.

\section{Statistical analysis}

Data analysis was performed using Prism 8 (GraphPad Software). Graphs in figures show Mean (horizontal lines) \pm SD (error bars) unless indicated otherwise. The bar graphs of FRAP data show median as a line, quartiles, maximum, and minimum (Figure 4B). A two-tailed student's t test was performed to determine statistical differences between two sets of data. An ANOVA was performed to determine statistical differences between sets of data.

\section{ACKNOWLEDGEMENTS}

We thank members of the Moseley laboratory for helpful discussions and comments on the manuscript; as well as the Biomolecular Targeting Core (BioMT) (P20-GM113132) and the Imaging Facility at Dartmouth for use of equipment; and Sophie Martin, Jian-Qiu Wu, Pilar Perez, and Juan Carlos Ribas for sharing yeast strains. This work was funded by a grant from the National Institutes of General Medical Sciences (NIGMS) (R01GM099774) to J.B.M. 


\section{REFERENCES}

Abenza JF, Couturier E, Dodgson J, Dickmann J, Chessel A, Dumais J, Carazo Salas RE (2015) Wall mechanics and exocytosis define the shape of growth domains in fission yeast. Nat Commun 6:8400.

Atilgan E, Magidson V, Khodjakov A, Chang F. (2015) Morphogenesis of the Fission Yeast Cell through Cell Wall Expansion. Curr Biol. 25:2150-7.

Bähler J, Wu JQ, Longtine MS, Shah NG, McKenzie A, Steever AB, Wach A, Philippsen P, Pringle JR (1998) Heterologous modules for efficient and versatile PCR-based gene targeting in Schizosaccharomyces pombe. Yeast 14:943-951.

Bendezú FO, Martin SG (2011) Actin cables and the exocyst form two independent morphogenesis pathways in the fission yeast. Mol Biol Cell 22:44-53.

Bendezú FO, Vincenzetti V, Martin SG (2012) Fission yeast sec3 and Exo70 are transported on actin cables and localize the exocyst complex to cell poles. PLoS One 7: e40248.

Bendezú FO, Vincenzetti V, Vavylonis D, Wyss R, Vogel H, Martin SG (2015) Spontaneous Cdc42 Polarization Independent of GDI-Mediated Extraction and Actin-Based Trafficking. PLoS Biol 13: e1002097.

Boström P, Andersson L, Rutberg M, Perman J, Lidberg U, Johansson BR, Fernandez-Rodriguez J, Ericson J, Nilsson T, Borén J, Olofsson SO (2007) SNARE proteins mediate fusion between cytosolic lipid droplets and are implicated in insulin sensitivity. Nat Cell Biol 9:1286-1293.

Chiou J, Balasubramanian MK, Lew DJ (2017) Cell Polarity in Yeast. Annu Rev Cell Dev Biol 33:77-101.

Choi MG, Kim MJ, Kim DG, Yu R, Jang YN, Oh WJ (2018) Sequestration of synaptic proteins by alphasynuclein aggregates leading to neurotoxicity is inhibited by small peptide. PLoS One 13: e0195339.

Cortés JCG, Carnero E, Ishiguro J, Sánchez Y, Durán A, Ribas JC (2005) The novel fission yeast $(1,3) \beta$-D-glucan synthase catalytic subunit Bgs4p is essential during both cytokinesis and polarized growth. J Cell Sci 118:157-174.

Cortés JC, Pujol N, Sato M, Pinar M, Ramos M, Moreno B, Osumi M, Ribas JC, Pérez P (2015) Cooperation between Paxillin-like Protein Px11 and Glucan Synthase Bgs1 Is Essential for Actomyosin Ring Stability and Septum Formation in Fission Yeast. PLoS Genet. 11: e1005358.

Das M, Wiley DJ, Medina S, Vincent HA, Larrea M, Oriolo A, Verde F (2007) Regulation of cell diameter, For3p localization, and cell symmetry by fission yeast Rho-GAP Rga4p. Mol Biol Cell 18:2090-2101.

Dee Tay Y, Leda M, Goryachev AB, Sawin KE (2018) Local and global Cdc42 guanine nucleotide exchange factors for fission yeast cell polarity are coordinated by microtubules and the Tea1-Tea4-Pom1 axis. J Cell Sci 131: jcs216580.

Deng L, Kabeche R, Wang N, Wu JQ, Moseley JB (2014) Megadalton-node assembly by binding of Skb1 to the membrane anchor Slf1. Mol Biol Cell 25:2660-2668.

Deng L, Moseley JB (2013) Compartmentalized nodes control mitotic entry signaling in fission yeast. Mol Biol Cell 24:1872-1881.

Feierbach B, Chang F (2001) Roles of the fission yeast formin for3p in cell polarity, actin cable formation and symmetric cell division. Curr Biol 11:1656-1665. 
Feierbach B, Verde F, Chang F (2004) Regulation of a formin complex by the microtubule plus end protein tea1p. J Cell Biol 165:697-707.

Fraldi A, Annunziata F, Lombardi A, Kaiser HJ, Medina DL, Spampanato C, Fedele AO, Polishchuk R, Sorrentino NC, Simons K, Ballabio A (2010) Lysosomal fusion and SNARE function are impaired by cholesterol accumulation in lysosomal storage disorders. EMBO J 29:3607-3620.

Ganesan SJ, Feyder MJ, Chemmama IE, Fang F, Rout MP, Chait BT, Shi Y, Munson M, Sali A (2020) Integrative Structure and Function of the Yeast Exocyst Complex. Protein Sci. doi: 10.1002 pro.3863.

Goehring NW, Grill SW (2013) Cell polarity: Mechanochemical patterning. Trends Cell Biol. 23:72-80.

Jourdain I, Dooley HC, Toda T (2012) Fission Yeast Sec3 Bridges the Exocyst Complex to the Actin Cytoskeleton. Traffic 13:1481-1495.

Kelly FD, Nurse P (2011) Spatial control of Cdc42 activation determines cell width in fission yeast. Mol Biol Cell 22:3801-3811.

Kokkoris K, Castro DG, Martin SG (2014) The Tea4-PP1 landmark promotes local growth by dual Cdc42 GEF recruitment and GAP exclusion. J Cell Sci 127:2005-2016.

Kroschwald S, Maharana S, Mateju D, Malinovska L, Nüske E, Poser I, Richter D, Alberti S (2015) Promiscuous interactions and protein disaggregases determine the material state of stress-inducible RNP granules. Elife 4: e06807.

Martin SG, Arkowitz RA (2014) Cell polarization in budding and fission yeasts. FEMS Microbiol Rev. 38: 228-53.

Martin SG, McDonald WH, Yates JR, Chang F (2005) Tea4p links microtubule plus ends with the formin for3p in the establishment of cell polarity. Dev Cell 8:479-491.

Martin SG, Chang F (2006) Dynamics of the formin for3p in actin cable assembly. Curr Biol. 16:1161-70.

Martin SG, Rincón SA, Basu R, Pérez P, Chang F (2007) Regulation of the formin for3p by cdc42p and bud6p. Mol Biol Cell. 18:4155-67.

Mata J, Nurse P (1997) tea1 and the microtubular cytoskeleton are important for generating global spatial order within the fission yeast cell. Cell 89:939-949.

Mitchison JM, Nurse P (1985) Growth in cell length in the fission yeast Schizosaccharomyces pombe. J Cell Sci 75:357-376.

Moreno S, Klar A, Nurse P (1991) Molecular genetic analysis of fission yeast Schizosaccharomyces pombe. Methods Enzymol 194:795-823.

Moseley JB, Mayeux A, Paoletti A, Nurse P (2009) A spatial gradient coordinates cell size and mitotic entry in fission yeast. Nature 459:857-860.

Nakano K, Imai J, Arai R, Toh-e A, Matsui Y, Mabuchi I (2002) The small GTPase Rho3 and the diaphanous/formin For3 function in polarized cell growth in fission yeast. J. Cell Sci. 115:4629-4639.

Ng AYE, Ng AQE, Zhang D (2018) ER-PM Contacts Restrict Exocytic Sites for Polarized Morphogenesis. Curr Biol 28:146-153.e6.

Patel SS, Belmont BJ, Sante JM, Rexach MF (2007) Natively Unfolded Nucleoporins Gate Protein Diffusion across the Nuclear Pore Complex. Cell 129:83-96.

Pelham HRB (1999) SNAREs and the secretory pathway - Lessons from yeast. Exp. Cell Res. 247:1-8.

Polgar N, Fogelgren B (2018) Regulation of Cell Polarity by Exocyst-Mediated Trafficking. 
Cold Spring Harb Perspect Biol. 10: a031401.

Protopopov V, Govindan B, Novick P, Gerst JE (1993) Homologs of the synaptobrevin/VAMP family of synaptic vesicle proteins function on the late secretory pathway in S. cerevisiae. Cell 74:855-861.

Pruyne D, Legesse-Miller A, Gao L, Dong Y, Bretscher A (2004) Mechanisms of polarized growth and organelle segregation in yeast. Ann Rev Cell Dev Biol 20:559-591.

Revilla-Guarinos MT, Martín-García R, Antonia Villar-Tajadura M, Estravís M, Coll PM, Pérez $\mathrm{P}$ (2016) Rga6 is a fission yeast Rho GAP involved in Cdc42 regulation of polarized growth. Mol Biol Cell 27:1524-1535.

Ribbeck K, Görlich D (2002) The permeability barrier of nuclear pore complexes appears to operate via hydrophobic exclusion. EMBO Journal. 21:2664-71.

Rothman JE (1994) Intracellular membrane fusion. Adv Second Messenger Phosphoprotein Res 29:81-96.

Snaith HA, Thompson J, Yates JR, Sawin KE (2011) Characterization of Mug33 reveals complementary roles for actin cable-dependent transport and exocyst regulators in fission yeast exocytosis. J Cell Sci 124:2187-99.

Söllner T, Whiteheart SW, Brunner M, Erdjument-Bromage H, Geromanos S, Tempst P, Rothman JE (1993) SNAP receptors implicated in vesicle targeting and fusion. Nature 362:318-324.

Südhof TC, Rothman JE (2009) Membrane fusion: Grappling with SNARE and SM proteins. Science 323:474-477.

Tatebe H, Shimada K, Uzawa S, Morigasaki S, Shiozaki K (2005) Wsh3/Tea4 is a novel cell-end factor essential for bipolar distribution of teal and protects cell polarity under environmental stress in S. pombe. Curr Biol 15:1006-1015.

Tatebe H, Nakano K, Maximo R, Shiozaki K (2008) Pom1 DYRK regulates localization of the Rga4 GAP to ensure bipolar activation of Cdc42 in fission yeast. Curr Biol. 18:322-30.

Tay YD, Leda M, Spanos C, Rappsilber J, Goryachev AB, Sawin KE (2019) Fission Yeast NDR/LATS Kinase Orb6 Regulates Exocytosis via Phosphorylation of the Exocyst Complex. Cell Reports 26:1654-1667.

TerBush DR, Maurice T, Roth D, Novick P (1996) The Exocyst is a multiprotein complex required for exocytosis in Saccharomyces cerevisiae. EMBO J 15:6483-6494.

Wang H, Tang X, Balasubramanian MK (2003) Rho3p regulates cell separation by modulating exocyst function in Schizosaccharomyces pombe. Genetics 164:1323-1331.

Wang H, Tang X, Liu J, Trautmann S, Balasundaram D, McCollum D, Balasubramanian MK (2002) The multiprotein exocyst complex is essential for cell separation in Schizosaccharomyces pombe. Mol Biol Cell 13:515-529.

Wang N, Lee IJ, Rask G, Wu JQ (2016) Roles of the TRAPP-II Complex and the Exocyst in Membrane Deposition during Fission Yeast Cytokinesis. PLoS Biol 14:e1002437.

Zhu Y-H, Hyun J, Pan Y-Z, Hopper JE, Rizo J, Wu J-Q (2018) Roles of the fission yeast UNC13/Munc13 protein Ync13 in late stages of cytokinesis. Mol Biol Cell 29:2259-2279. 


\section{FIGURE LEGENDS:}

Figure 1: Psy1 localizes to Skb1-SIf1 nodes at non-growing regions of the PM. (A) GFPPsyl nodes do not overlap with actin marker Lifeact-mCherry. Images are from deconvolved zseries. Dashed arrow marks monopolar cell; arrowhead marks bipolar cell; arrow marks dividing cell. (B) Co-localization of GFP-Psy1 and mCherry-Slf1. Representative images with boxed region of close up of mCherry and GFP node signals (Right) are shown. (C) Left, Coimmunoprecipitation of mCherry-Slf1 and GFP-Psy1 from fission yeast cells. Right, Coimmunoprecipitation of 6His-Skb1 and GFP-Psy1. (D) Global and local quantification (A.U.) of GFP-tagged Psy1, Skb1, and Slf1 proteins. (E) Skb1 and Slf1 are required for Psy1

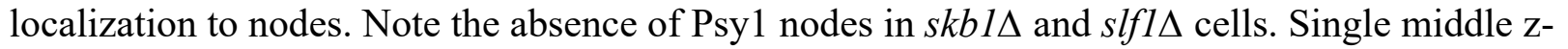
slice images are shown (top). Scale bars $4 \mu \mathrm{m}$.

Figure 2: Psy1 nodes are stable structures. (A) FRAP analysis of GFP-Psy1 nodes. Representative cell before and after photobleaching. The red boxed region was bleached. (B) Time-lapse imaging of GFP-Psy1. Kymographs (Right) show distribution of GFP-Psy1 in boxed region at nodes (\#2), or along lines at cell tips (\#1 and \#3). (C) GFP-psyl mCherry-slf1 cells were treated with 10\% 1,6-hexanediol or DMSO control. Images (right) are close ups of the white boxed region showing intact Skb1-Slf1-Psy1 nodes. Maximum intensity projections were created from the top half of cell z-stack images that encompass one side of the cell membrane. Bar, $4 \mu \mathrm{m}$.

Figure 3: Genetic evidence for Skb1-SIf1-Psy1 node function in exocytosis. (A) Septation index in cells of indicated strains at $32^{\circ} \mathrm{C}$ (Left) or $37^{\circ} \mathrm{C}$ (Right). Growth defects or suppression with $s k b 1 \Delta$ is indicated by a black or green line, respectively. $\mathrm{n}>100$ per strain. (B) Blankophor staining of indicated strains, showing cell separation defects in exo $70 \Delta$, exo $70 \Delta \mathrm{skb1 \Delta}$, sec8-1, and $\sec 3-2$ strains grown at $37^{\circ} \mathrm{C}$. Bar, $7 \mu \mathrm{m}$. (C) Psyl overexpression rescues sec 3-2 growth. Cells transformed with empty $p R E P 41$ or with $p R E P 41-G F P-p s y 1$ were spotted with $10 \times$ serial dilutions onto EMM-Leu plate supplemented with $10 \mu \mathrm{g} / \mathrm{ml}$ thiamine. Excess GFP-Psy1 expression was confirmed by fluorescence microscopy.

Figure 4: Loss of Skb1-Slf1-Psy1 nodes leads to changes in the pattern of exocytosis. (A) FRAP curves of GFP-Bgs 4 at cell tips or the division site in WT or $s k b 1 \Delta$ cells. Representative images of cells expressing GFP-Bgs4 are shown. $n>10$ cells for each strain. (B) Plateau of

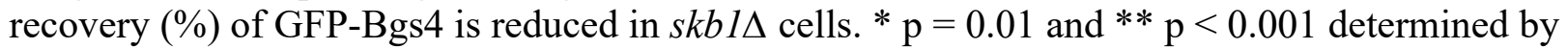

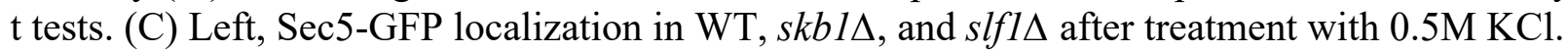
Arrows point to ectopic Sec5 signal in $s k b 1 \Delta$ and slf1 $1 \Delta$ cells. Bar, $4 \mu \mathrm{m}$. Right, Quantification of cells (\%) with ectopic Sec5 localization on cell sides. Error bars indicate SEM. $\mathrm{n}>100$ cells for each strain (D) Localization of Sec8-mNG in the indicated strains. To the right of each single cell image is a kymograph showing Sec8 localization along cell sides (yellow arrow) over time. (E) Normalized mean intensity of Sec8-mNG along cell sides for the indicated strains. $\mathrm{n}>25$ for each strain. Error bars indicate SEM. ${ }^{*} \mathrm{p}<0.04$ and $* * \mathrm{p}<0.0001$ determined by ANOVA.

Figure 5: Nodes contribute to cell width control (A) Cell width $(\mu \mathrm{m})$ of indicated cell types. $* * \mathrm{p}=0.0001$ and $* * * \mathrm{p}<0.0001$ determined by ANOVA. $\mathrm{n}>50$ for each cell type. (B) 
Representative images showing wider cells with $s k b 1 \Delta$. Bars, $4 \mu \mathrm{m}$. (C) Working model for polarized morphogenesis through inhibition of exocytosis along the sides of fission yeast cells. Green circles denote Psy1 sequestered by Skb1-Slfl nodes (blue circles) along cell sides. Rga4 and Rga6 (Purple circles) inhibit Cdc42-GTP at these sites. Cdc42-GTP denoted as a broad red band directs actin cable (black arrows) organization to cell tips. Cables act as tracks for secretory vesicles that fuse to the PM through the action of SNARE Psy1 (broad green band at tips) to facilitate growth.

\section{Supplemental Figure Legends:}

Figure S1: Additional images from 1,6-hexanediol assays. (A) WT cells expressing P-body marker Sts5-GFP grown to saturation and then treated with 10\% 1,6-hexanediol or DMSO control. (B) Middle z-section images of WT cells expressing GFP-Psy1 and mCherry-Slf1 treated with 10\% 1,6-hexanediol or DMSO control. Arrows point to a portion of S1f1 displaced from nodes and present at cell sides and tips. Bars, $4 \mu \mathrm{m}$.

Figure S2: Genetic interactions between node mutants and exocytosis mutants. (A) Table summarizing growth of indicated single or double mutants shown below. Red shaded rows indicate temperature sensitive growth with double mutants compared to single mutants. Green shaded rows indicate growth suppression with double mutants. (B) The indicated strains were spotted with $10 \times$ serial dilutions onto YE4S or YE4S $+0.5 \mathrm{M} \mathrm{KCl}$ plates. Plates incubated for 24 days prior to imaging.

Figure S3: Additional analysis of Skb1-Slf1-Psy1 nodes with Rga4 and Rga6 GAPs. (A) Cell width in $\mu \mathrm{m}$ of indicated cell types. ${ }^{*} \mathrm{p}<0.01$, $* * \mathrm{p}=0.0001$, and $* * * \mathrm{p}<0.0001$ determined by ANOVA. $\mathrm{n}<50$ for each cell type. (B) Localization of Rga4-mNG (Left) or Rga6-GFP (Right) and mCherry-Slf1 in WT cells. Representative images with boxed region of close up of mCherry and GFP node signals (Right panels) are shown.

Table S1. Yeast strains used in this study

\begin{tabular}{|c|c|c|}
\hline Strain & Genotype & Source \\
\hline JM6543 & pAct1-Lifeact-mCherry::leu+GFP-psy1::kanMX6 & This Study \\
\hline JM4209 & GFP-psy1::kanMX6 mCherry-slf1::kanMX6 & This Study \\
\hline JM4497 & GFP-psy1::kanMX6 mCherry-slf1::kanMX6 skb1د::natR & This Study \\
\hline JM4207 & GFP-Psy1::kanMX6 skb1 $\Delta:: n a t R$ & Lab collection \\
\hline JM4467 & GFP-psyl::kanMX6 slf1D::hphR & This Study \\
\hline JM4200 & GFP-psy1::kanMX6 & This Study \\
\hline JM2325 & skb1-GFP::kanMX6 h- & Lab collection \\
\hline JM1801 & slf1-GFP::kanMX6 h+ & Lab collection \\
\hline
\end{tabular}




\begin{tabular}{|c|c|c|}
\hline JM366 & $972 h-$ & Lab collection \\
\hline JM906 & 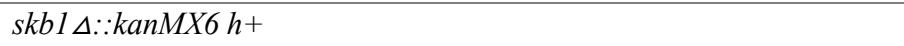 & Lab collection \\
\hline JM909 & skb1 $\Delta::$ ura $4+$ ura4-D18 leu1-32 & Lab collection \\
\hline JM656 & sec8-1 ura4-D18 leul-32 h+ & Lab collection \\
\hline JM1449 & exo70::kanMX6 ura4-D18 leu1-32 ade6-M21X h+ & Lab collection \\
\hline JM665 & for $3 \Delta::$ kanMX6 ura4-D18 leu1-32 ade6-M21X h+ & Lab collection \\
\hline JM6226 & sec3-2-his5+-ura+ ade6-leu1-ura4D-18 h- & (Bendezú et al., 2012) \\
\hline JM6256 & rho3s::kanMX6 h- & This Study \\
\hline JM6057 & skb1 $\Delta:: k a n M X 6$ exo70 $\Delta:: k a n M X 6$ ura $4-D 18$ & This Study \\
\hline JM6262 & 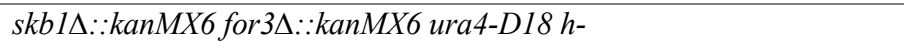 & This Study \\
\hline JM6113 & skb14::kanMX6 sec8-1 ura4-D18 leu1-32 h- & This Study \\
\hline JM6313 & 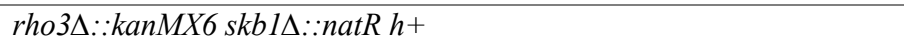 & This Study \\
\hline JM6374 & sec3-2-his5+-ura+ skb1ه::natR ura4-D18 h- & This Study \\
\hline JM6112 & slf1 $1 \Delta:: h p h R h-$ & This Study \\
\hline JM6127 & slf1 $\Delta:: h p h R$ exo $70 \Delta:: k a n M X 6 h-$ & This Study \\
\hline JM6264 & slf1 $\triangle:: h p h R$ for $3 \Delta:: k a n M X 6 h-$ & This Study \\
\hline JM6330 & 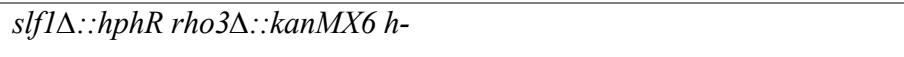 & This Study \\
\hline JM6357 & slf1 $::$ hphR sec8-1 ura4-D18 leul-32 h+ & This Study \\
\hline JM6420 & slf1 $::$ kanMX6 sec3-2-his5+-ura4+ ura4-D18 leu1-32 & This Study \\
\hline JM6211 & bgs $4 \Delta:: u r a 4+$ Pbgs $1+:: G F P-b g s 4+: l e u 1+$ skbl $1 \Delta: N A T h+$ & This Study \\
\hline JM4011 & leu1-32 ura4-18 his3-1 bgs $4 \Delta:: u r a 4+P b g s 1+:: G F P-b g s 4+: l e u 1+h-$ & (Cortes et al., 2005) \\
\hline JM6228 & sec5-GFP::kanMX6 ade6-m216 leu1-32 ura4-D18 h- & (Bendezú et al., 2012) \\
\hline JM6331 & sec5-GFP::kanMX6 skb1 $:: n a t R h-$ & This Study \\
\hline JM6350 & 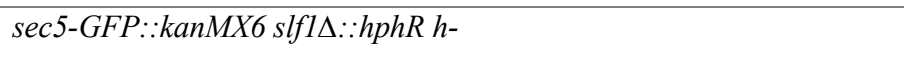 & This Study \\
\hline JM6362 & 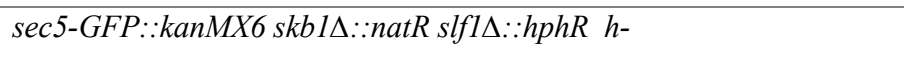 & This Study \\
\hline JM6087 & sec8-mNeonGreen::hphR $h^{+}$ & This Study \\
\hline JM6398 & 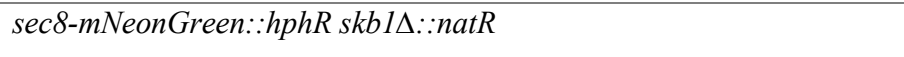 & This Study \\
\hline JM6641 & skb1 $1:: n a t R$ for $3 \Delta:: k a n M X 6$ sec8-mNeonGreen::hphR $h+$ & This Study \\
\hline JM6643 & for $3 \Delta:: k a n M X 6$ sec8-mNeonGreen::hphR $h+$ & This Study \\
\hline JM6669 & 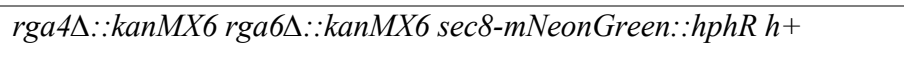 & This Study \\
\hline JM6671 & 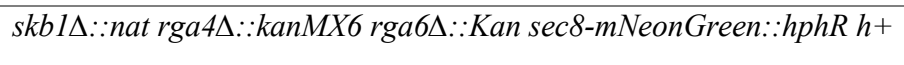 & This Study \\
\hline JM508 & skb1 $:: k a n M X 6 h-$ & This Study \\
\hline JM2139 & slf1 $1:: h p h R h^{+}$ & This Study \\
\hline JM1807 & 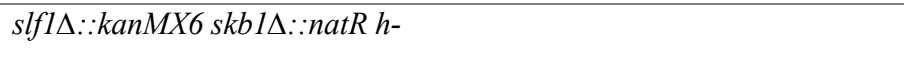 & This Study \\
\hline JM6224 & 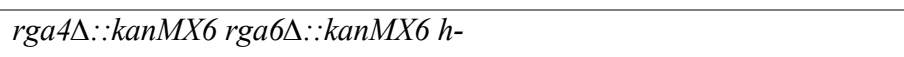 & This Study \\
\hline
\end{tabular}


bioRxiv preprint doi: https://doi.org/10.1101/2020 05.01.072553; this version posted May 3, 2020. The copyright holder for this preprint (which was not certified by peer review) is the author/funder, who has granted bioRxiv a license to display the preprint in perpetuity. It is made available under aCC-BY-NC-ND 4.0 International license.

\begin{tabular}{|c|c|c|}
\hline JM6225 & 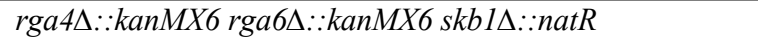 & This Study \\
\hline JM6171 & $\operatorname{rga} 4 \Delta:: k a n M X 6 h-$ & This Study \\
\hline JM6170 & $\operatorname{rga} 4 \Delta:: k a n M X 6$ skb1 $1:: n a t R h+$ & This Study \\
\hline JM6172 & rga64::kanMX6h+ & This Study \\
\hline JM6167 & $\operatorname{rga} 6 \Delta:: k a n M X 6$ skb1 $1:: n a t R h-$ & This Study \\
\hline JM6464 & 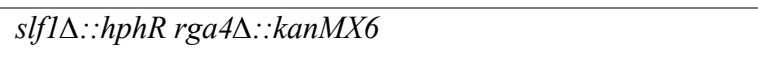 & This Study \\
\hline JM6465 & 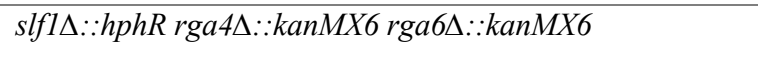 & This Study \\
\hline JM6114 & Pslf1-mCherry-slf1::kanMX6 rga4-mNeonGreen::hphR $h$ - & This Study \\
\hline JM6124 & Pslf1-mCherry-slf1::kanMX6 rga6-GFP::kanMX6 h+ & This Study \\
\hline
\end{tabular}


A

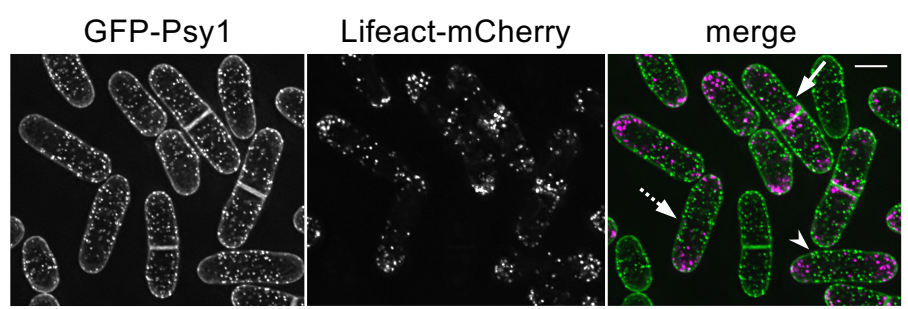

B
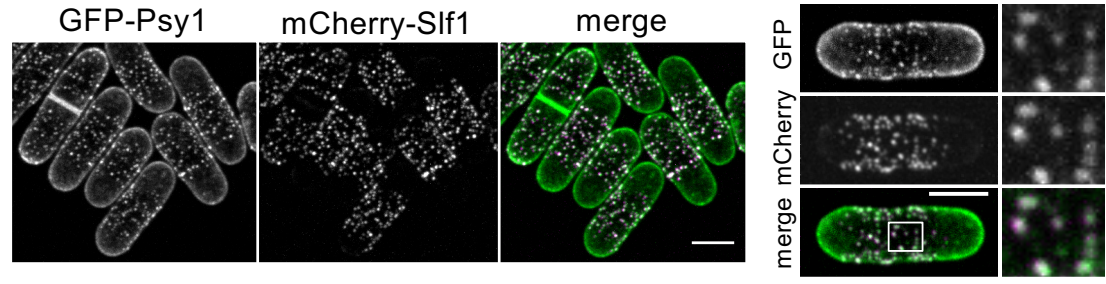

C

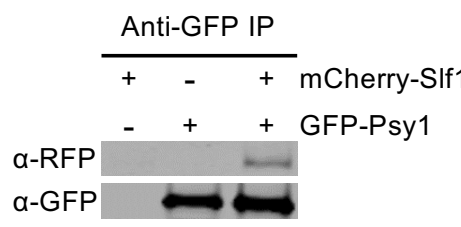

Anti-His IP

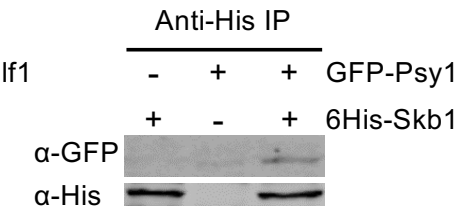

D
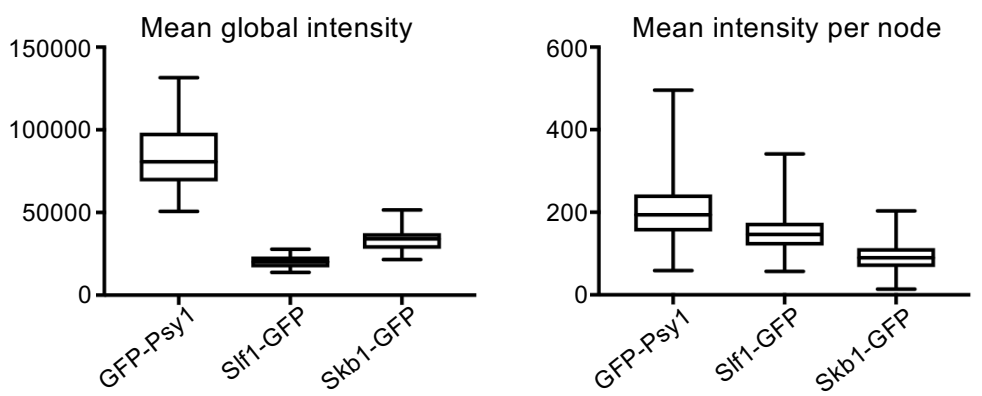

E

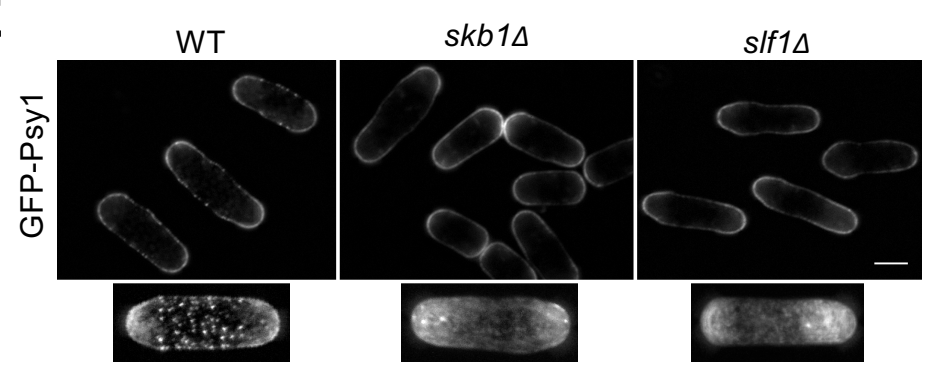


bioRxiv preprint doi: https://doi.org/10.1101/2020.05.01.072553; this version posted May 3, 2020. The copyright holder for this preprint (which was not certified by peer review) is the author/funder, who has granted bioRxiv a license to display the preprint in perpetuity. It is made available under aCC-BY-NC-ND 4.0 International license.

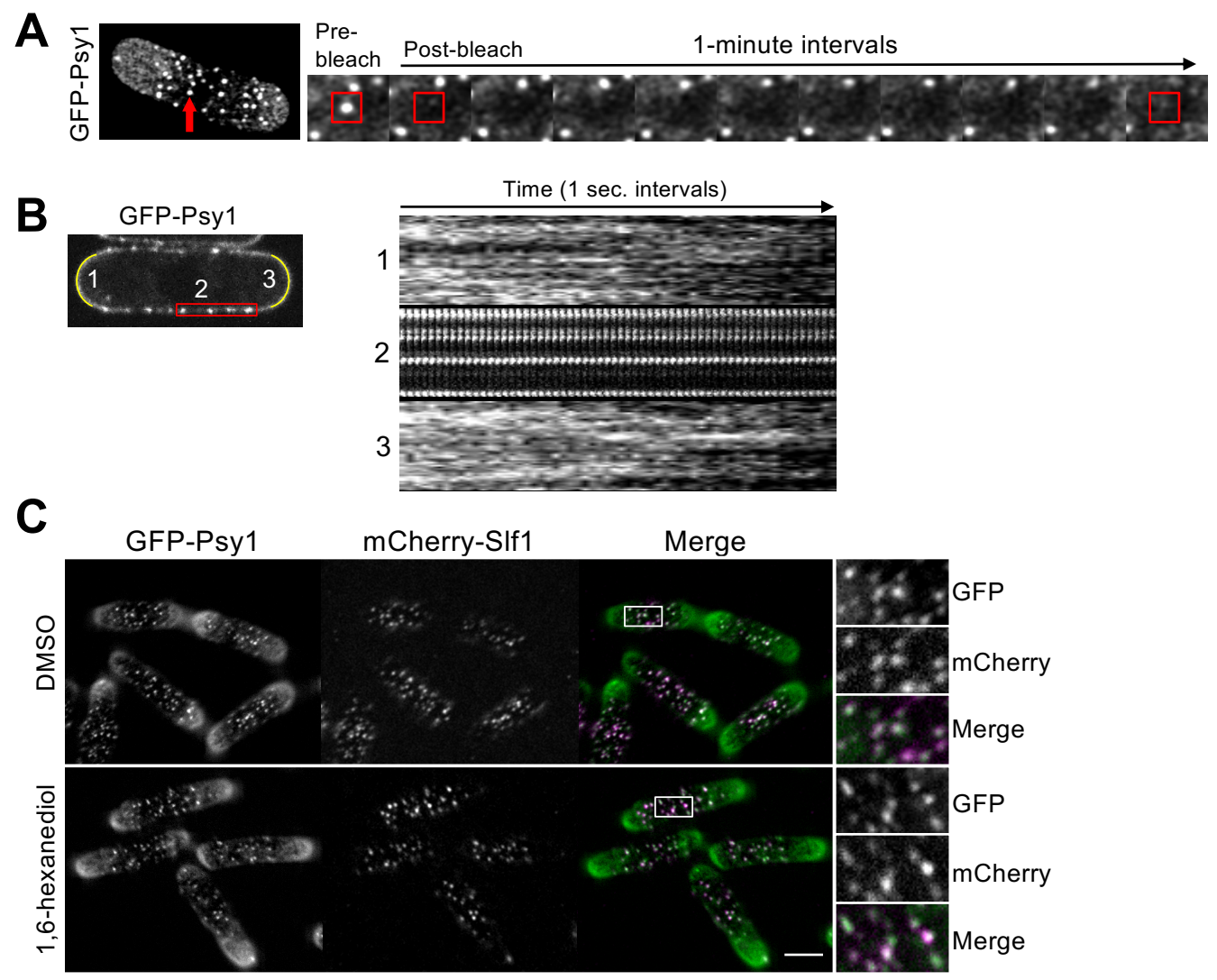


A

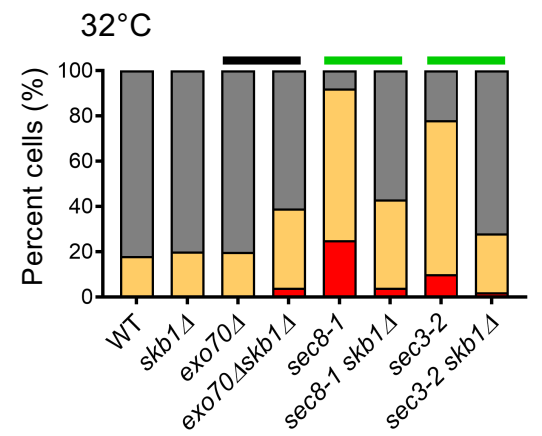

$37^{\circ} \mathrm{C}$

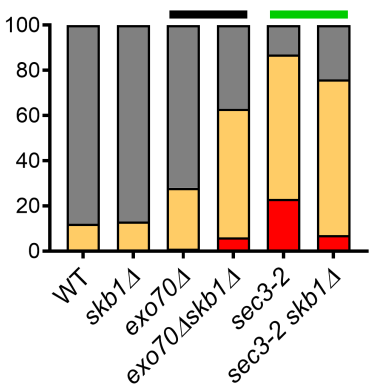

$\square$ No septum

$\square$ Single septum

Multiple septa

B
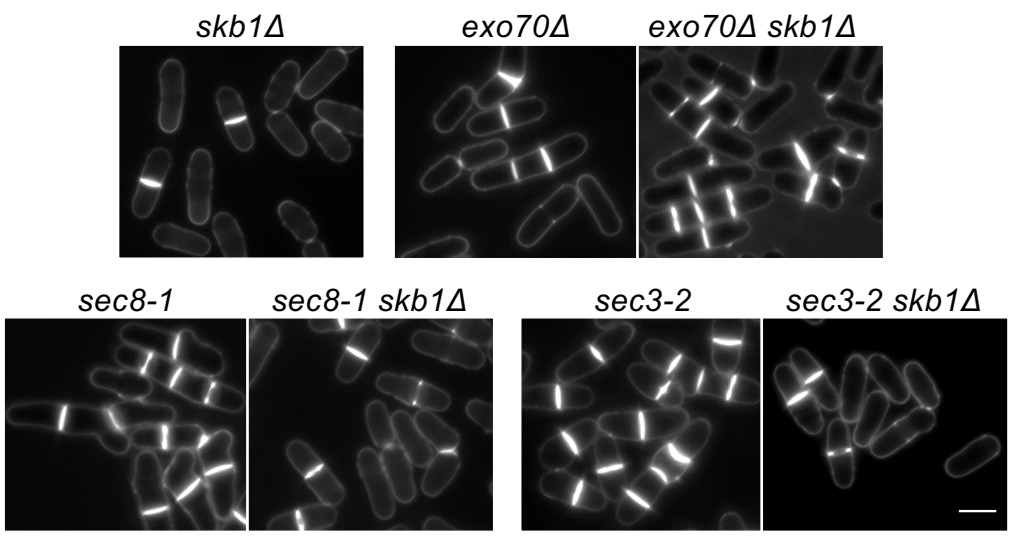

C

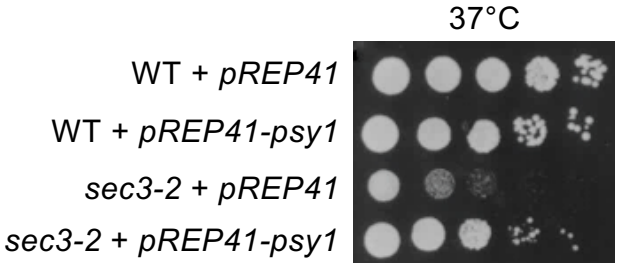


bioRxiv preprint doi: https://doi.org/10.1101/2020.05.01.072553; this version posted May 3, 2020. The copyright holder for this preprint (which was not certified by peer review) is the author/funder, who has granted bioRxiv a license to display the preprint in perpetuity. It is made available under aCC-BY-NC-ND 4.0 International license.

A

$$
\begin{array}{ll} 
& \text { Cell tips } \\
\text { GFP-Bgs4 } &
\end{array}
$$

WT: $\mathrm{t}_{1 / 2}=61.8 \mathrm{~s}$

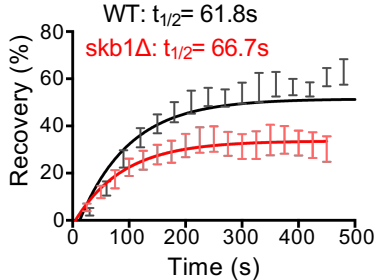

C

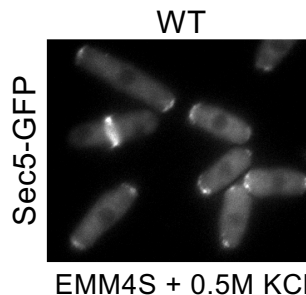

D

Sec8-mNG

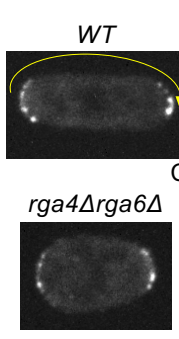

for $3 \Delta$
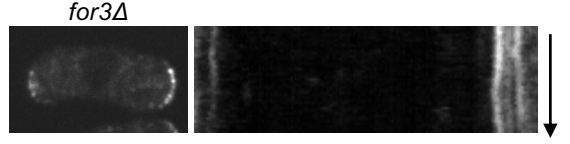

E

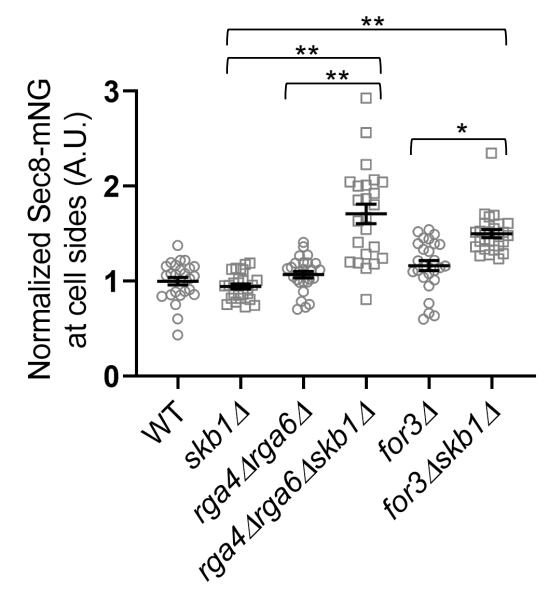

Division site

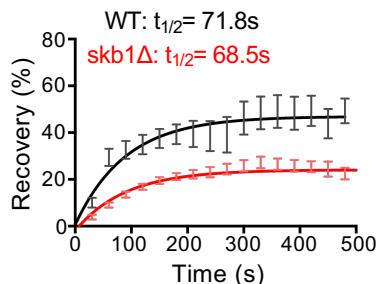

$s k b 1 \Delta$
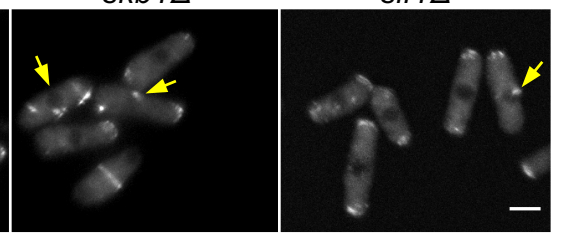

slf1 $\Delta$
B

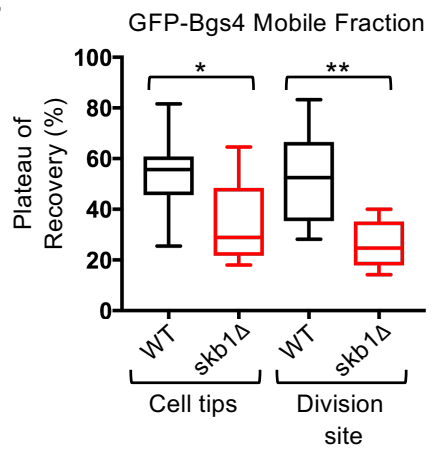

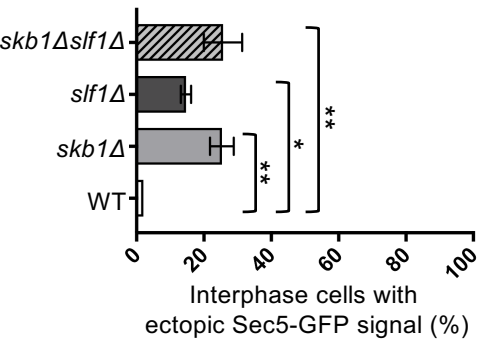

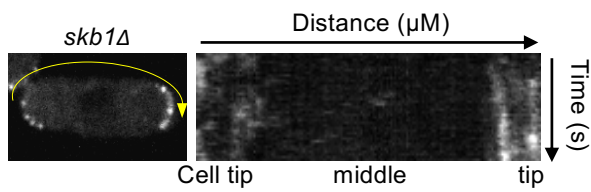

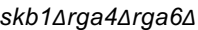
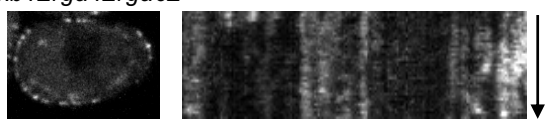

skb1 1 for $3 \Delta$
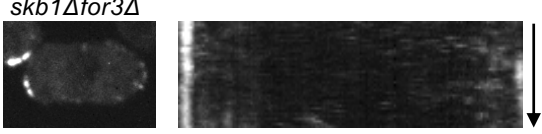
bioRxiv preprint doi: https://doi.org/10.1101/2020 05.01.072553; this version posted May 3, 2020. The copyright holder for this preprint (which

was not certified by peer review) is the author/funder, who has granted bioRxiv a license to display the preprint in perpetuity. It is made available under aCC-BY-NC-ND 4.0 International license.

A

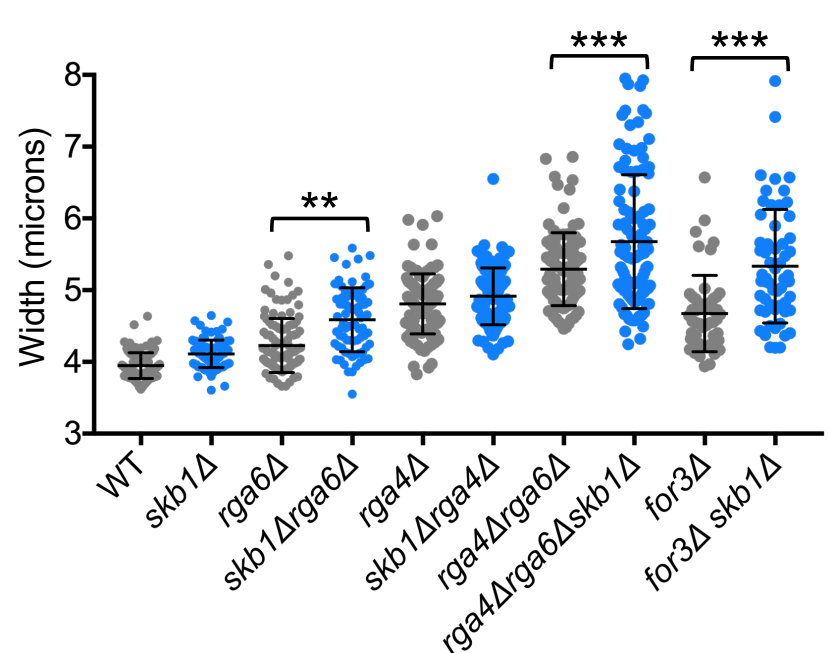

B

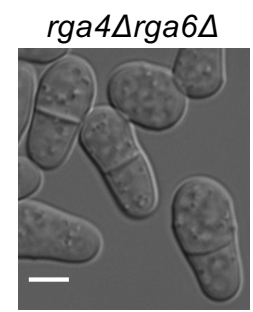

for3 $\Delta$ skb1 1 rga $4 \Delta r g a 6 \Delta$

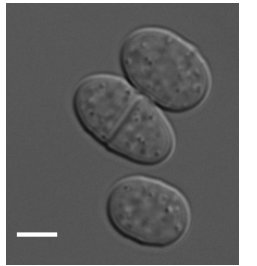

for $3 \Delta s k b 1 \Delta$
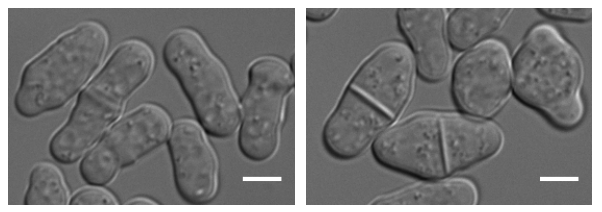

C

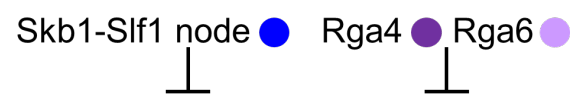

Psy1 Cdc42-GTP

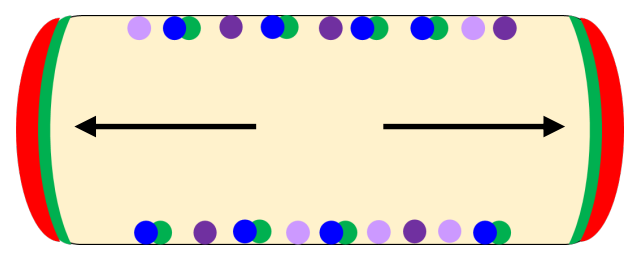


bioRxiv preprint doi: https://doi.org/10.1101/2020.05.01.072553; this version posted May 3, 2020. The copyright holder for this preprint (which was not certified by peer review) is the author/funder, who has granted bioRxiv a license to display the preprint in perpetuity. It is made available under aCC-BY-NC-ND 4.0 International license.

A

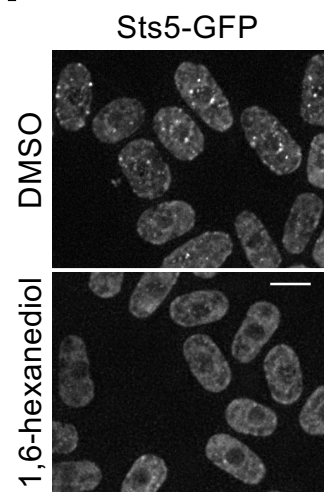

B

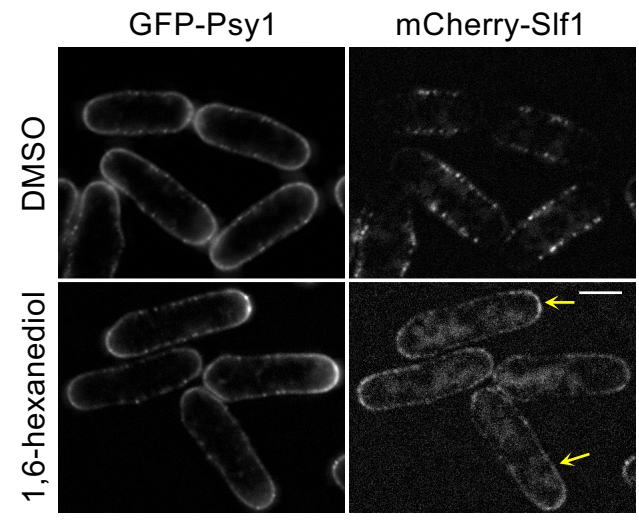


bioRxiv preprint doi: https://doi.org/10.1101/2020.05.01.072553; this version posted May 3, 2020. The copyright holder for this preprint (which was not certified by peer review) is the author/funder, who has granted bioRxiv a license to display the preprint in perpetuity. It is made available under aCC-BY-NC-ND 4.0 International license.

A

Summary of growth assays

\begin{tabular}{|c|c|c|c|}
\hline & Single mutant & with skb1 $\Delta$ & with slf1 $\Delta$ \\
\hline exo70 $\Delta$ & + & - & - \\
\hline for3 $\Delta$ & + & - & - \\
\hline $\operatorname{sec3}-2$ & + & ++ & + \\
\hline $\sec 8-1$ & + & ++ & ++ \\
\hline rho3 $\Delta$ & + & ++ & ++ \\
\hline
\end{tabular}

,+ typical growth of single mutant

++ , enhanced growth

-, reduced growth

B

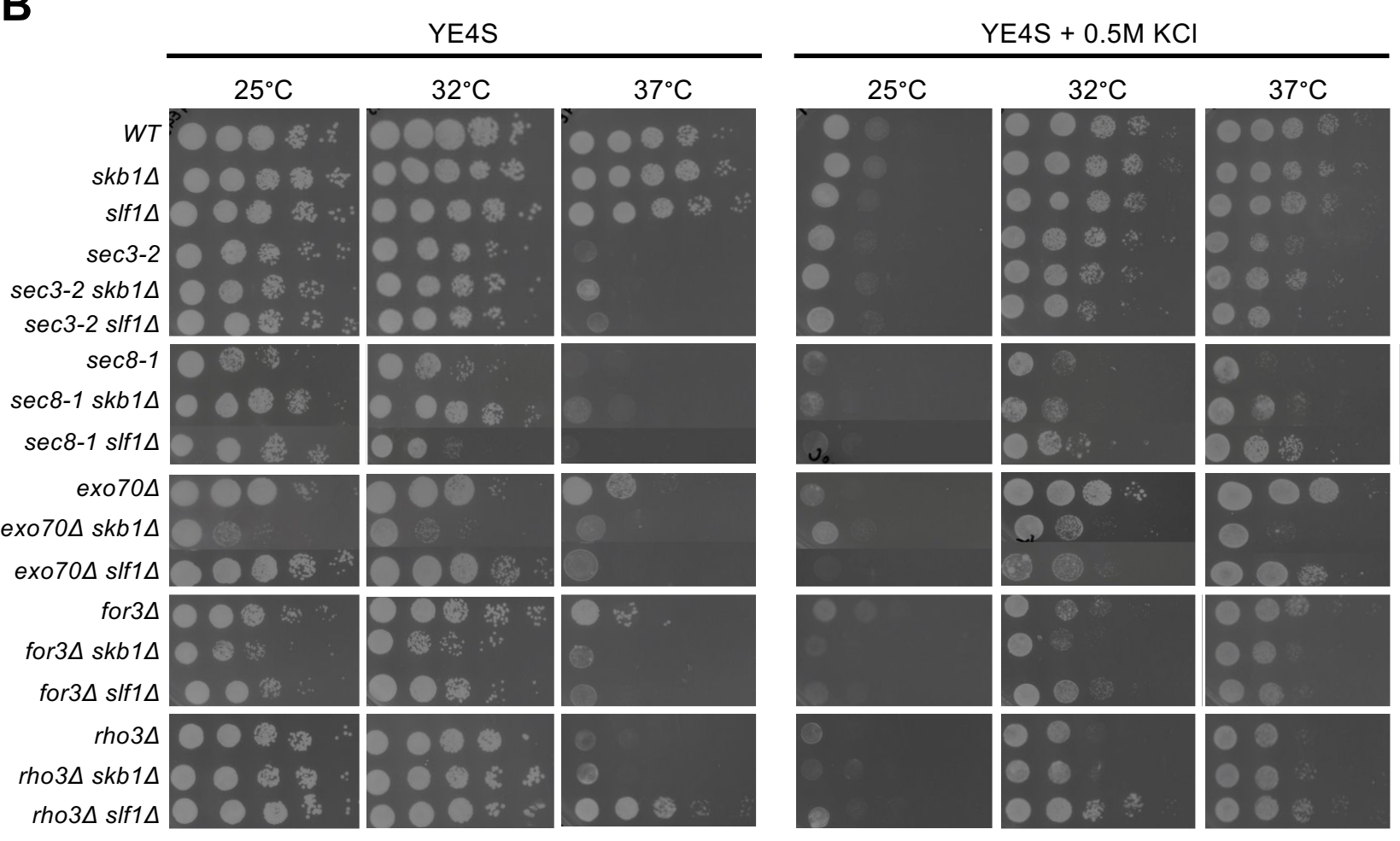




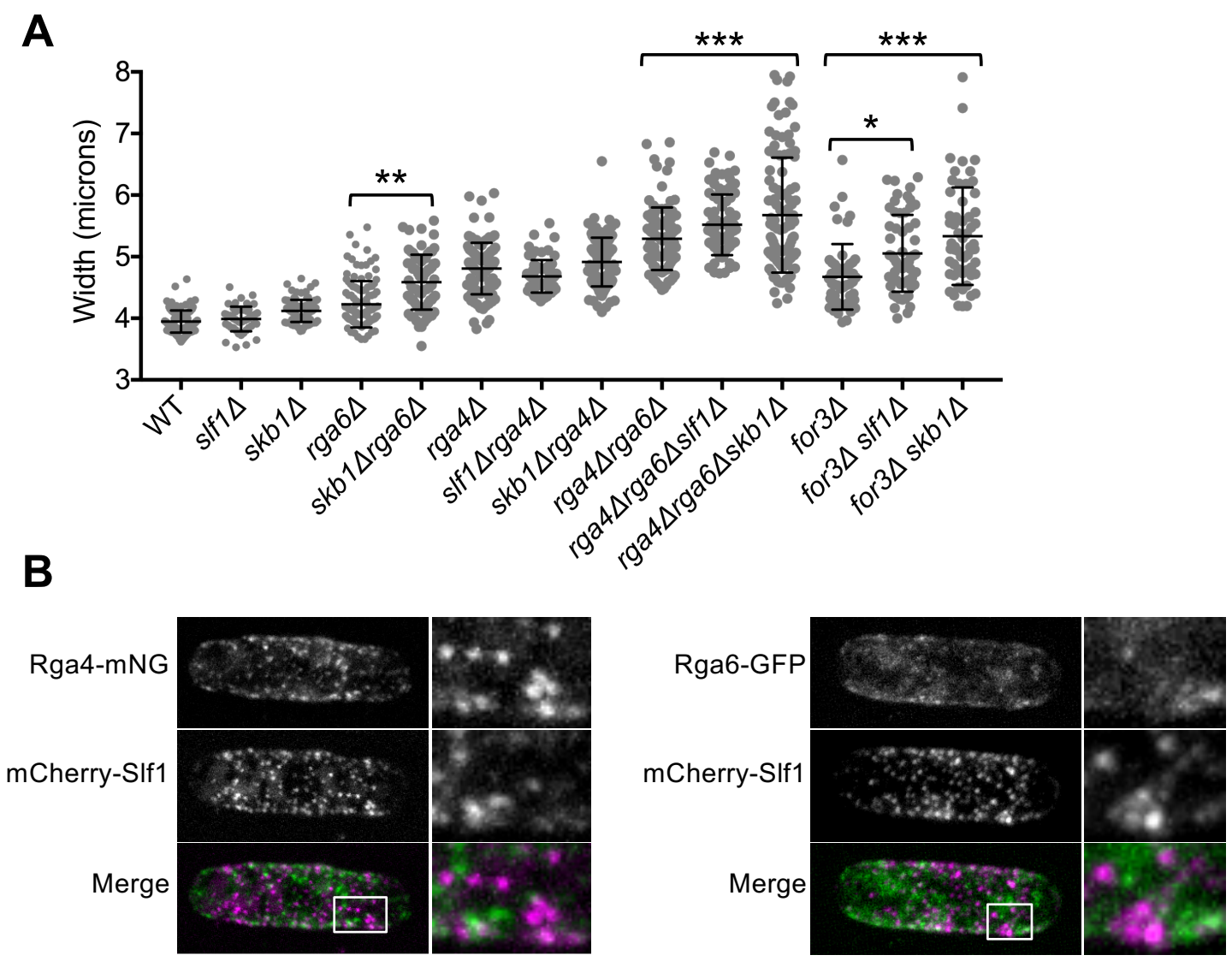

